China Perspectives

47 | May-june 2003

Varia

\title{
The snares of modernity
}

Internet, information and the SARS crisis in China

\section{Éric Sautedé}

\section{(2) OpenEdition}

\section{Journals}

Édition électronique

URL : http://journals.openedition.org/chinaperspectives/273

DOI : $10.4000 /$ chinaperspectives. 273

ISSN : 1996-4617

Éditeur

Centre d'étude français sur la Chine contemporaine

Édition imprimée

Date de publication : 1 juin 2003

ISSN : 2070-3449

\section{Référence électronique}

Éric Sautedé, "The snares of modernity », China Perspectives [En ligne], 47 | May-june 2003, mis en ligne le 18 septembre 2006, consulté le 28 octobre 2019. URL : http://journals.openedition.org/ chinaperspectives/273; DOI : 10.4000/chinaperspectives.273

Ce document a été généré automatiquement le 28 octobre 2019

(c) All rights reserved 


\title{
The snares of modernity
}

Internet, information and the SARS crisis in China

\author{
Éric Sautedé
}

\section{NOTE DE L'ÉDITEUR}

Translated from the French original by Michael Black

1 The SARS ${ }^{1}$ crisis has already had a significant impact on China's economy, politics and society, and will have an even greater impact in the near future. Without getting into a debate between poles, whether it was a "Chinese Chernobyl"2 or a "benign crisis" 3 , the authorities' handling of this emergency and the damage this crisis implies now appear to have a potential for destabilisation which is likely to send in a more political direction the great reform project begun 25 years ago. The reason is simple: this crisis highlights all the contradictions of the Chinese development model, the inequality it has generated, and the obsolescence of a certain mode of government which is ferociously monopolistic within a context of extraordinary diversification; all this in an endogenous manner, first in the cities, then in the country, while making china, although a member of the UN Security Council, if not a "rogue state" at least a state whose international responsibility is doubtful and apparently impervious to the notion of "global concern". At the origin of this lack of responsibility one finds the question of freedom of information in China, since the pretence of transparency displayed by the Chinese government since April $20^{\text {th }} 2003$ only began after six months of mendacity and dissimulation, while official rhetoric continued to insist unswervingly that: "the situation is under control". Without outside pressure, first from Hong Kong's Chinese language press and the international press, then from the World Health Organisation (WHO)-and only because the crisis has taken a dramatic turn which was highly damaging to Hong Kong and then to Peking-, and without the courage of a few Chinese doctors also, in whose eyes the imperative of public health made this denial of reality increasingly dangerous, it seems evident that the Chinese Communist Party would not have been brought around to "communicating", not to mention giving out information, as it is doing now. The cardinal role played by the former British colony needs to be 
underlined here: Hong Kong's misfortune has been the good fortune of the population of China and of the rest of the world, precisely because freedom of expression there isso far-protected.

It therefore seems vital to ask ourselves about the inconsistencies of information in China, and particularly about the role of modern means of communication and information during this crisis, which, while these have not been totally absent, especially the mobile phone, did not fulfil the "alternative" role that they are too often attributed.

While overall this may come as no surprise, it seems useful at this point to remind ourselves of the politically restrained context in which over 60 million Chinese internauts "surf", to think about the contradictions which arise between "communication" and "information", and to show how highly pragmatic the skill of the Chinese government has been in making concessions towards liberalisation only in those areas where its legitimacy could not be threatened and in misrepresenting its propaganda by subtle-and modern-artifices. In the final analysis, this updating of propaganda is as much a response to the demand for modernity in deception as the result of the deception of modernity.

Panoptical temptation and interstitial expressions of freedom

Information on Chinese Information Superhighway is still tightly controlled ${ }^{4}$, upstream by the restrictions imposed on providers and by regulations, and downstream by penalties. This systematic bleeding of the Internet, which at best is "on parole", largely explains the medium's lack of responsiveness to the SARS crisis.

5 Firstly, on the international connectivity side, the restrictions imposed are both technical and political. With some 59.1 million internauts and a bandwidth of 9.4 gigabytes per second (gbps) in $2002^{5}$, China seems to come out well, and growth figures since 1995 have been considerable. A comparison makes it possible to relativise this triumphalism about volume. Thus if we take the single example of Taiwan, where there were "only" 8.6 million internauts in $2002^{6}$, the bandwidth reached $14.8 \mathrm{gbps}^{7}$, which means that there are almost seven times as many internauts in China who have, however, only two-thirds the international bandwidth that the Taiwanese enjoy. From a more qualitative standpoint, we know, on the basis of scattered information, that some foreign sites are inaccessible from China. The sites of the big English language press organs (Washington Post, Herald Tribune, CNN, BBC, etc.) as well as the sites of foreign organisations interested in subjects deemed to be politically sensitive-Tibet, Taiwan, Falungong, Human Rights in China, etc.-are the favoured targets of this denial of access. The recent study produced by a Harvard Law School research team directed by Jonathan Zittrain and Benjamin Edelman ${ }^{8}$ provides incontrovertible confirmation of the existence of this practice, since of the 200,000 websites to which they simulated access from China between May and November of 2002, 50,000 were "somehow" inaccessible at least in one instance and one locality, and 19,000 were inaccessible several times over while being simultaneously accessible from the United States. Besides the sites mentioned above, several content providers linked to education, and more precisely to the field of health were regularly blocked. This is in particular the case of the AIDS Healthcare Foundation, Internet Mental Health and the research project Health in China ${ }^{9}$.

6 The filtering of the data available on the Chinese Internet, both on the web and in news groups, is also standard practice in China. All the commercial Chinese sites which 
provide news or "spaces for public expression" practice it. Internet cafés themselves are supposed to install programs which memorise the activity of users, who must first give proof of identity to the manager of the establishment. The major campaigns to bring order back to the cyber cafés in the spring of 2001, and in the spring and summer of 2002 seem to have borne fruit in this area. The filtering methods are well known, since the technology used was "sold" by big foreign companies such as America's Cisco Systems and Global One (a joint venture between Sprint, France Telecom and Deutsche Telekom), who knowingly dismissed its ultimate application ${ }^{\mathbf{1 0}}$. The existence of "data packet sniffers" which make it possible to identify "subversive" foreign sites, of email filters and of Big Mamas on newsgroups is now largely recognised, and was even directly admitted by the Chinese authorities when, in October 2002, Beijing yule xinbao (Beijing Entertainment News) discussed "leaks" in certain filtering systems ${ }^{\mathbf{1 1}}$. A recent investigation by Reporters sans frontières, carried out with the help of a Chinese BBC journalist, also showed clearly that the news groups hosted by the big Chinese content providers-sina.com.cn, sohu.com, yahoo.com.cn and tom.com-were subjected to the continuous attention of the censors ${ }^{12}$.

7 Several forms of regulatory restriction make up the control mechanism. These are aimed at users as well as at service and content providers. It would take too long to recapitulate the history of these regulations here, the first of which date back to February 1996. The most important among them are: the Measures for Managing Internet Information Services issued by the State Council in September 2000, which make it illegal for content providers-thus making them responsible-to disseminate information which the government deems to be damaging and "unhealthy"; and the Regulations for Managing News Services on the Internet, promulgated in November 2000, which define the content which is forbidden on Chinese news groups and news sites, and restrains the dissemination of information from foreign media (in short, all information which might come into the wide and ill-defined category of "state secrets"). Moreover, since December 2000, all deviant uses of the Internet have been "criminalised", since they have been made to conform with the articles of the Criminal Law which deal with "crimes endangering national security". Other measures with more ambiguous legal status are also in force, such as the Good Conduct Charter imposed, in March 2002, by the Chinese Internet Association on the major news portals and search engines, which has 130 signatories, including Yahoo! China; or the more straightforward regulations introduced in November 2002 by the Ministry of Culture to restrict the operations of Internet cafes ${ }^{13}$.

8 Lastly, those who breach these regulations face severe penalties. According to the American organisation Digital Freedom Network, some 34 people have been sent to prison for "crimes" connected to dissident use of the Internet since January $2000^{\mathbf{1 4}}$. While this may not seem to be a large number-the cases are, however, far from having all been registered and, when freedom is in question, the existence of even a single case of restriction deserves to be exposed-, the "crimes" of which the offenders were accused reveal the broad-mindedness of the Chinese government when it comes to the definition of the dissemination of State Secrets and of subversion: detention before trial and heavy sentences are applicable not only to those who circulate Chinese email addresses to dissident sites, to the webmaster of a site deemed to be subversive, to those who sign online petitions calling for the relaxation of certain restrictions, but 
also to anyone who makes public their disapproval when they discover that an internaut has been jailed for having signed the petition!

The case of Huang Qi, who was arrested on June $3^{\text {rd }} 2000$, is particularly interesting, and has just reached its final stage since this webmaster from Chengdu was sentenced in May 2003, to five years' imprisonment for subversion. His site, www.6-4tianwang.com (in reference to the repression on June $4^{\text {th }} 1989$ ), was made up of forums searching for missing persons and, more "serious", had dared to reproduce articles in Chinese calling for the revision of the official judgement on the events of May and June 1989. Huang Qi was charged under articles 103 and 105 of the Criminal Law ${ }^{\mathbf{1 5}}$, the former aimed at " whoever organises, plots, or acts [...] and instigates to split the country or undermine national unification", the latter at "whoever organises, plots, or acts [...] and instigates to subvert the political power of the state and overthrow the socialist system". While "organisation, plotting or any other act" are subject to the heaviest sentences (from three years to life imprisonment depending on the degree of responsibility), mere "instigation" is punishable by a sentence of "a maximum of five years of fixed-term imprisonment, criminal detention, control, or deprivation of political rights", except for "the ringleaders or those whose crimes are serious", who are liable to a "minimum" of five years without remission. It seems that Huang Qi was not charged with "acts" of subversion, but the incitement "by the spreading of rumours and calumny" for which he was found guilty earned him the maximum sentence for his "virtual crime" in its least harmful form, or the minimum sentence for it in its most serious form ${ }^{\mathbf{1 6}}$. There is little doubt that it is the same article 105 which may be cited when the 107 people already arrested in 17 provinces for having circulated false rumours about SARS in telephone messages or on the Internet, are charged ${ }^{17}$.

As we can see, the control architecture of the Internet in China only allows at best interstitial and temporary freedom of expression. Only the most experienced manage to circumvent censorship, at the risk of serious consequences. The efficiency of the control, by regulation and its application, is not merely the expression of real power, but makes it also possible, in Foucault's formulation, to take into account the singular existence of individuals, imposing a "continuous and minutely detailed prescriptive constraint", punishing individual practice, so that the censorship exercised by the public authorities brings in its wake the other major element in this panoptical perspective: the preventive self-censorship practised by Chinese commercial operators...and users.

SMS versus the Internet

11 Overall, the Internet has been subject to the same restrictions as the printed press as far as SARS is concerned, and compelled to conform to the demands of the propaganda organs of the Chinese Communist Party. Except for the small window of relative virtual freedom which appeared between April $4^{\text {th }}$ and $17^{\text {th }}$, a time of hesitation during which the new leadership team led by President Hu Jintao and Prime Minister Wen Jiabao was preparing to launch its national campaign against lies and the epidemic, only the circulation of subversive messages by mobile phone, the famous short messages (SMS) -in Chinese xiaolingtong-really surprised the Chinese government and foreign observers by their volume and independence of tone. Quite naturally, in a context of total disinformation and because the SARS epidemic had as its main centre first Guangdong, and then Peking, the volume of text message exchange was particularly high, since that is where the highest number of mobile phone users is to be found, with 
penetration rates (the number of subscribers as a proportion of the population) exceeding $60 \%$, which is to say close to that of most developed countries.

However, both the messages sent and the nature of the medium should make us exceedingly cautious about the position of this means of communication when it is called on to play a substitute role for which it is not a priori designed. Communication does not mean information, and while SMS admittedly mould new forms of sociability, they remain an interpersonal, private means of communication which has unrivalled advantages of immediacy, of dispersal capacity and of portability. Outside this enlarged private sphere there is absolutely no hierarchy or intrinsic value in the information. Evidence of this is that while massive exchanges of SMS in Guangdong ${ }^{18}$ in February led to crowds pouncing on Chinese pharmacopoeia and on vinegar to combat the unknown and non-admittable? illness, they nevertheless did not in themselves lead to national awareness. As far as content goes, and this proved to be the case once more in Peking in April, false rumours were much more numerous than true ones, notwithstanding a few cutting messages aimed at the authorities, most merely reported cases of SARS, whether proven or not. The flight of native or adoptive Pekingers to the countryside was certainly accelerated by the exchange of SMS, particularly when these announced that the Chinese army was going to "bombard the capital with insecticide" or that the government was about to impose martial law, but they did not in any way, for such is not their purpose, lead to the mobilisation of demonstrators challenging the hierarchs of Zhongnanhai in the empty streets. As for the degree of tolerance shown by the government in the face of these rumours which cause "social disorder", we can affirm unquestionably that it is all a question of degree, and once the surprise was over, the repression was bound to be severe.

The other major explanation for the initial relative tolerance of the public authorities towards the frantic exchange of texts is economic. All the telephone companies-which are all state companies-, even the fixed-line operators, provide such services. This needs to be underlined, since the two fixed-line telephone companies, China Telecom and China Netcom, are supposed to concentrate exclusively on fixed-line communication and therefore operate in this field in complete illegality since there is no regulation of text message licences. Nevertheless these two companies, thanks to SMS, now account for around $6 \%$ of the mobile market in China ${ }^{19}$. SMS and their income, while they are modest and tend to reduce prices, are now conceived as a strategic weapon in a context of fierce competition and price-cutting. While they are not the ideal antidote to the erosion of revenue per user, they are an indispensable weapon in the battle for market share: with 95 million SMS exchanged in 2002, income has increased fourfold compared to 2001, reaching 6 billion yuan ${ }^{\mathbf{2 0}}$, while in the same period the number of users grew by $42 \%$ (61.4 million new subscribers), overall income from mobile telephony rose by only $19 \%$, to a total of 192.4 billion yuan, and revenue per user fell by $19 \%$. The situation is made worse by the fact that users of prepaid cards now amount to $23 \%$ of all subscribers, and they are notorious for their shorter call time ${ }^{21}$. These SMS resources seem bound to go on growing, since, according to telecom specialists, the major part of the approximately 200 billion yuan in capital investment announced by the Chinese operators in 2003 is likely to go into mobile message systems $^{22}$.

14 Once the surprise was over, the measure taken of the danger of the true and false rumours, and the perspective of a drop in income admitted, the Chinese government 
quickly took the measures necessary to reduce its threshold of tolerance, for although they were not information, the numerous "rumours" carried by the SMS went against the new dispensation of a national mobilisation in the fight against SARS. As noted above, there have already been more than a hundred arrests directly linked to the circulation of rumours, and a technician who had worked on setting up a new method of screening confided that China Mobile and China Unicom singled out subscribers who sent more than a hundred messages an hour, and that these messages, as well as all their addressees, could be read by the authorities in less than fifteen minutes ${ }^{23}$.

The distortions of propaganda

With the decision to at last recognise reality, after the special meeting of the Politburo Standing Committee on April $17^{\text {th24 }}$, during which President $\mathrm{Hu}$ Jintao agreed to acknowledge that the government had lied and went into reverse to mobilise the Party in a united front to struggle against the epidemic threatening the capital and the entire nation, the initial measures taken by the government were energetic. On the communication front, this meant firstly a big press conference organised by the State Council's Information office, during which the deputy Minister for Health Gao Qiang, in the Minister's absence, suddenly revised upwards the total of SARS cases (over three hundred cases in Peking), called the situation "serious and worrying"-to the point of cancelling the traditional and "golden" week-long May Day holiday-and agreed to give clear answers to the somewhat embarrassing questions put by the Chinese and foreign journalists present in the room. Only a few hours later, it was learned that the Minister for Health, Zhang Wenkang, although close to Jiang Zemin, and the mayor of Peking, Meng Xuenong, had been sacked from their posts because of their failures in managing the epidemic.

Much more than the meeting on April $17^{\text {th }}$, inevitably held in camera, it was the press conference on April $20^{\text {th }}$ which sounded the death knell of the cult of secrecy and of preventive dissimulation. Can we, for all that, conclude that this is the inauguration of a new era of transparency? Or on the contrary, are we not merely witnessing a new dressing-up of propaganda when denial is no longer an option? The April $20^{\text {th }}$ press conference has been reproduced in its entirety on a number of Chinese websites and all the major portals, whether state (xinhua.net, people.com.cn) or commercial (sina.com.cn, sohu.com, netease.com), have overflowed, since that day, with extremely precise information on the illness and on the government's action to fight against it. All in all, we have gone from total ignorance in which the ordinary urbanite had heard rumours on his telephone about the virtues of vinegar in the fight against SARS and for whom the only alternative was to follow the adage of Galen, the famous first century Greek anatomist and "leave as soon as possible, go as far away as possible, and come back as late as possible", to a situation of absolute "information overkill" in which anyone with an Internet connection can keep abreast of the latest developments in the genetic decoding of the virus, and simultaneously download the latest song commissioned by the government which proclaims over a rousing tune that victory over the illness is at hand.

What is surely the most convincing example of this modernised propaganda can be seen on the SARS pages of the Chinese Medical and Biological Information site hosted by the Institute of Cardiovascular Sciences of Peking University ${ }^{25}$. This is an extremely informative site containing the latest figures for SARS infections and deaths, their distribution by province, the preventive measures to be taken, the latest statements 
from Chinese specialists and political leaders, highly illustrated diagrams on the means of transmission, sectional drawings of the virus, a number of articles from the Chinese language press, and even some articles from the foreign press (Washington Post, Reuters, etc). Once the effect of surprise has passed-the reproduction of foreign articles is forbidden in China, unless sanctioned by the organs of public security, and the Washington Post site, for example, is blocked-and one looks more carefully at these articles, one realises that in reality they are all about technical or scientific aspects of the epidemic and that the links to be clicked on in order to read the articles are in reality hosted on the same site, but that, in order to be authentic, the presentation and the logos have been faithfully reproduced to give the impression that a door to the outside has been opened...

Both the efficiency of the methods of control described above and the know-how deployed by the Chinese authorities on the Information Superhighway seem to contradict any idea of a "revolution of and by information". They also make obsolete the somewhat ossified vision of China's "current generation of Soviet-trained leaders" being impervious to these new means of communication because they supposedly cannot escape "notions of modernity where planning, heavy industry and electricity represented progress"26.

Modern snares and the delusion of modernity

The new and biased excesses of over-communication cannot be allowed to conceal the sad reality: were it not for the courage of some members of the health profession in the context of very strong international pressure, the situation of mendacity cultivated by the Chinese authorities might have continued until the epidemic played itself out-the optimistic scenario-or until a burgeoning health crisis appeared in the Chinese countryside in return-the pessimistic scenario. The question which then arises is whether their accounts were motivated more by generalised popular discontent maintained by modern communication tools-which seems unlikely given the inertia of disinformation in the weeks which followed the peaking of the infection in Guangdong in February 2003-or, on the contrary, by their "humanist" duty as health professionals at a time when the eyes of the rest of the world were riveted on Hong Kong and China, and when the WHO team present in China was showing great determination in its efforts to unearth the truth-the first recommendation by the WHO to travellers not to visit Peking was issued on March $27^{\text {th }}$.

Much more than the rumours which circulated among Pekingers or Cantonese, it was in fact the "free rider" attitude of certain members of the medical profession which forced the government to open up and reconsider the denial which had been in force for several months. At the forefront was the retired military doctor Jiang Yanyong, already known in China and abroad for the positions he had taken in support of the students who demonstrated in Tiananmen Square in 1989. After the press conference given on April $3^{\text {rd }}$ by the Minister for Health Zhang Wenkang, according to whom the situation in China was "safe" and the SARS epidemic "effectively under control", Jiang Yanyong sent an email the next day to China's central television and to the Hong Kong station Phœnix, in which he accused Zhang of lying and revealed that in the hospitals he knew in Peking alone, there were at least one hundred cases of SARS and that no fewer than six people had died of it (as against the 12 cases officially recognised) ${ }^{27}$. His email was not initially acted on, but it was transmitted to various foreign press organs and, on April $8^{\text {th }}$, his statements were taken up by the German weekly Der Spiegel, and 
on April $9^{\text {th }}$ appeared on the website of the major American weekly Time. Jiang Yanyong's statements then became very popular in China itself, and were widely distributed by email and posted on the $\mathrm{BBS}^{\mathbf{2 8}}$ of the universities, among them the very popular BBS Shuimou at Tsinghua University ${ }^{29}$. This sudden turn of events illustrates clearly both the potential and the limitations of the use of modern communications where information is concerned: the information which Jiang Yanyong possessed, and which he could just as well have passed on by telephone or by fax, was valid only because it was provided by a respected speaker and, once it had been widely taken up in the foreign press, was transformed into news. There is little doubt that the government's main worry was that this "free rider" attitude might become widespread, rather than the contradiction of the official version expressed on news groups, the latter being necessarily limited in scope and only too easily wiped clean.

21 An analysis of the health system in China, particularly in rural areas ${ }^{\mathbf{3 0}}$, which a number of studies now deem to be decrepit and highly discriminatory since it charges for its services, would go beyond the bounds of this article. However it may be useful to look again at certain data here and place them in a comparative perspective. Thus, if official figures are to be believed, in 2001 there were 2.1 million doctors in China, or, still according to official figures, six doctors per 100,000 inhabitants ${ }^{31}$. These overall figures include practitioners of traditional medicine and ignore the considerable differences between town and country, as well as between regions. In France, on January $1^{\text {st }} 2002$, there were 237,470 doctors, or 330 doctors per 100,000 inhabitants. ${ }^{32}$ If we look at mobile telephony, there were, in 2001, 206 million subscribers to mobile lines in China and 38.6 million in France. The respective penetration rates were $16 \%$ and $64.7 \%{ }^{33}$. While hasty conclusions are to be avoided, the fact remains, whether those who take an ordinary view of Chinese modernisation like it or not, that in terms of a highly modern and profitable "commercial service", China is in a ratio of 1 to 4 in comparison with a developed nation such as France. Meanwhile, when it comes to a "basic public service" the ratio is 1 to 55 ! There is a remarkable paradox here, when China's population can easily communicate and exchange information on the shortcomings of the public authorities without ever having the power to follow up the contradiction-there is no freedom of speech-much less to attempt to change things-there is no freedom of association.

THE WATCHWORD of the new leadership team, which emerged from the XVI ${ }^{\text {th }}$ Congress of the Chinese Communist Party in November 2002, seems to be to establish a "moderately prosperous society" (xiaokang shehui), thus showing that they want to correct disparities of wealth which have become too obvious and find ways to share growth more fairly. The consequences of the SARS crisis, to which must be added the unprecedented public admission, on May $1^{\text {st }}$, that a submarine had sunk with the loss of 70 crew members ${ }^{34}$, would seem to show that the regime will also have to take on board the demand for "moderately free information". Nevertheless, there is no doubt that the Chinese leaders will be keen to maintain a reduced conception of this "moderation", and recent developments on the Chinese Internet indicate very clearly that Pandora's Box, contrary to generally accepted ideas, simply remains only "half open". 


\section{NOTES}

1. SARS : Severe Acute Respiratory Syndrome of viral origin which has affected China in particular since November 2002, and the rest of the world since last March. In Chinese the name for SARS corresponds exactly to "atypical pneumonia" : feidianxing feiyan, or feidian for short. 2. Headline on the front of the British weekly The Economist, April $26^{\text {th }}$ 2003.

3. In the words of the mediagenic Chinese economist, Hu Angang, of Tsinghua University, as they appeared in Wenhuibao, May 11 2003. 4. For an early analysis which remains valid today, see Emmanuel Parody and Eric Sautedé, "Internet in China-Roadblocks on the information highway", China Perspectives, No. 1, September-October 1995, pp. 36-42. For more recent publications which give a good overview of methods of control see: Michael S. Chase and James C. Mulvenon, You've Got Dissent! Chinese Dissident Use of the Internet and Beijing's Counter-Strategies, Santa Monica, Ca., Rand Corporation, June 2002; Edward Yung, "Beyond the Great Firewall", China Economic Quarterly, October-December 2002, pp. 50-53; Shanti Kalathil and Taylor C. Boas, Open Networks, Closed Regimes-The Impact of the Internet on Authoritarian Rule, Washington D.C., Carnegie Endowment for International Peace, 2003.

5. http://www.cnnic.net.cn/develst/2003-1e/444.shtml.

6. http://www.dgt.gov.tw/Chinese/Datastatistics/11.3/annual-report-91/ internet-growth.shtml.

7. http://www.find.org.tw/0105/howmany/howmany_disp.asp?id=51.

8. http://cyber.law.harvard.edu/filtering/china/.

9. http://www.aidshealth.org/, http://www.mentalhealth.com/ and http:// www.healthinchina.com/.

10. Ethan Gutman, "Who Lost China's Internet ?", The Standard, February $25^{\text {th }} 2002$.

11. South China Morning Post, October $24^{\text {th }} 2002$.

12. Reporters sans frontières, "Vivre dangereusement sur le Net", May $12^{\text {th }} 2003$, http://www.rsf.fr/imprimer.php3?id-article $=6792$.

13. Xinhua, October $15^{\text {th }} 2002$.

14. For a profile of the jailed internauts see http://www.dfn.org/focus/ china/netattack.htm.

15. See http://www.6-4tianwang.com/nh/2000/200303012044.shtml.

16. Criminal Law of the People's Republic of China, revised on March $14^{\text {th }}$ 1997, Part II, Chapter 1 (Crimes endangering national security). 17. South China Morning Post, May $10^{\text {th }} 2003$.

18. Libération, April $3^{\text {rd }} 2003$.

19. Tara Tranguch, "Takes a Look at the Little Smart Mentality", Global Mobile, March 26 $6^{\text {th }}$ 2003, p. 16.

20. South China Morning Post, February $19^{\text {th }} 2003$.

21. MFC Insight Update, March $26^{\text {th }} 2003$. 
22. MFC Insight Update, April $18^{\text {th }} 2003$.

23. Reuters, May $12^{\text {th }} 2003$.

24. Washington Post, May $13^{\text {th }} 2003$.

25. http://cmbi.bjmu.edu.cn/cmbidata/sars/index.htm.

26. This conclusion, with which we disagree, comes from Tony Saich, and illustrates quite well the immoderate hopes which some writers, although experts on contemporary Chinese society and on the Chinese Communist government's adaptability in a context of rapid change, pin on the emergence of new transnational means of communication. See Tony Saich, Governance and Politics of China, New York, Palgrave, 2001, p. 310.

27. Washington Post, May $13^{\text {th }} 2003$.

28. Bulletin Board Services are news groups used on closed circuits such as those of a university, a company, etc.

29. Communication with students at Tsinghua.

30. Charlotte Cailliez, "The Collapse of the Rural Health System", China Perspectives, No. 18, July-August 1998, pp. 36-43.

31. National Statistical Bureau of China, Zhongguo tongji nianjian 2002 (China Statistical Yearbook 2002), September 2002, p. 776.

32. Figures from the French Medical Association, Conseil national de l'Ordre des médecins, available on the Internet at http://www.conseilnational.medecin.fr/.

33. See http://www.itu.int/ITU-D/ict/statistics/at_glance/cellular02.pdf. 34. On this point see Willy Wo-Lap Lam, "China Learns Cover-up Lessons", www.cnn.com, May $6^{\text {th }} 2003$. 